\title{
Population dynamics of anchovy pekto (Stolephorus waitei) in the waters of Malacca Strait, North Sumatra, Indonesia
}

\author{
MISWAR BUDI MULYA ${ }^{\bullet}$, ARLEN HANEL JHON, ZULHAM APANDY HARAHAP \\ Department of Biology, Faculty of Mathematics and Natural Sciences, Universitas Sumatera Utara. Jl. Bioteknologi No. 1, Medan 20155, North Sumatra, \\ Indonesia. Telp./fax.: +62-61-8211050, `email: miswar_bm@usu.ac.id
}

Manuscript received: 5 January 2021. Revision accepted: 14 June 2021.

\begin{abstract}
Mulya MB, Jhon AH, Harahap ZA. 2021. Population dynamics of anchovy pekto (Stolephorus waitei) in the waters of Malacca Strait, North Sumatra, Indonesia. Biodiversitas 22: 2693-2698. Anchovy pekto or Stolephorus waitei (Engraluidae: Clupeiformes) is one of the fish in the eastern coastal part of North Sumatra, occupying the waters of Malacca Strait. This research presents the population dynamics of $S$. waitei following its age, growth, mortality, and recruitment pattern based on the length-frequency data. Fork length (FL) and total weight (TW) data of $S$. waitei were collected at three sites from April to September 2018. A total of 1994 specimens with FL from 4.0 to $6.7 \mathrm{~cm}$ and TW from 0.2 to $2.3 \mathrm{~g}$ with the length-weight relationship of $T W=0.073 \mathrm{FL}^{3.0046}\left(R^{2}=0.765\right)$ indicated a near isometric and positive allometric growth in the water region. The relative condition factor $\left(K_{n}\right)$ ranged from 1.01 to 1.02 , indicating an estimate of good condition of the fishes. The growth parameters based on von Bertalanffy was $6.56 \mathrm{~cm}\left(L_{\infty}\right)$ with the growth coefficient $(K)$ of $0.34 \mathrm{yr}^{-1}$ and $t o$ (anchovy age at zero length ) of 0.6506 . The total mortality $(Z)$, natural mortality $(F)$, and catch mortality $(M)$ of $S$. waitei were $0.64,1.39$, and $0.75 \mathrm{yr}^{-1}$ respectively, which suggest that the fishing activities of $S$. waitei are still in normal intensity. The recruitment pattern of S. waitei was stable between April and August with its peak in June by $14.21 \%$. The fishing activities may then be limited during the spawning months (May to June) of $S$. waitei to maintain their population in the Strait of Malacca.
\end{abstract}

Keywords: Growth pattern, Malacca Strait, population dynamics, recruitment pattern, Stolephorus waitei

\section{INTRODUCTION}

Anchovies are one of the important marine fishery resources in the Indo-Pacific region, including Stolephorus spp. or white baits, the most intensively harvested member of the groups commonly found in the tropical waters of Indonesia (Safruddin et al. 2018). Together with other small pelagics (sardines and herrings), anchovies provided the largest source of protein with annual productivity between $21 \%$ and $43 \%$ of the total marine commodities in the last 60 years (Cota et al. 2013). Anchovy pekto (S. waitei) or ikan teri pekto (Indonesian) is one of the relatively well harvested small fish species in North Sumatra among other 18 valid Stolephorus species from the family Engraulidae (Clupeiformes: Clupeioidei) distributed worldwide (Jordan and Seale 1926; Eschmeyer and Fricke 2008). The species is distinguishable by its uniformly pale brown body, a longitudinal silver band stretching from behind upper opercular margin to caudal-fin base, and a silver head with longer upper jaw (Whitehead et al. 1988; Wongratana et al. 1999; Hata et al. 2020). The distribution of this species is still reported only from Queensland, Australia (Hata et al. 2020) and Indo-Pacific: western Indian Ocean (from Cochin and southern tip of India to Myanmar) and western Pacific (Thailand, Java Sea, the Philippines, probably Irian Jaya, if not also Papua New Guinea, south to Queensland; perhaps even more widespread. A large population of anchovies was documented to dwell in the waters of Strait of Malacca, which is being harvested intensively following a high market demand in North Sumatra for human consumption. Anchovies are rich in calcium, iron, omega-3 oils and proteins yet preserved as low-cost salted and dried products with a high nutrient content (Siriskar et al. 2013). Therefore, the availability of this species in the Indonesian waters is regarded as a natural blessing, one of high-quality fish in economical value with export priority. The monitoring of fish stocks in nature is urgently needed to assess its current state of sustainability in the face of intensive harvesting by fishermen, and the magnitude of industrial processing for fish products (Masse et al. 2016). High market demand may lead to overfishing by fishermen along with a consequence upon their population decline in nature. Although the availability of anchovies is regarded as abundant in certain provinces of Indonesia, some aspects of their biological parameters are still neglected. Research on this issue is limited especially for $S$. waitei populations regarding their recent conditions, growth, requirement patterns, and natural or catch mortalities (Milton et al. 1998; Gamawan et al. 2018; Irnawati et al. 2018).

In addition, the biomass dynamics of S. waitei may be strongly dependent on recruitment which remains a question especially for the population occupying the waters of Strait of Malacca in North Sumatra, Indonesia. For years, Strait of Malacca has been studied for its major problems and issues of development in the coastal and marine resources with the gaps on some neglected fish species (Burbridge 1988). No information is currently available from the monitoring of $S$. waitei within the water region of the Strait of Malacca. Therefore, the present 
study reveals the significance of applied biology in fishery science to provide the biological data of $S$. waitei for the assessment of its stock and monthly population dynamics.

\section{MATERIALS AND METHODS}

\section{Study area and sampling sites}

This research was conducted in the water region of the Strait of Malacca, North Sumatra from April to September 2018. The fishing gears i.e. gill nets and trawls were provided by local fishermen. Monthly fork length (FL) data of $S$. waite $i$ were collected from three representative sites in an area extending from west to east of the region i.e. station I (3 $\left.29^{\prime} \mathrm{N}, 99^{\circ} 18^{\prime} \mathrm{E}\right)$, station II (3 $\left.29^{\prime} \mathrm{N}, 9^{\circ} 18^{\prime} \mathrm{E}\right)$, and station III $\left(03^{\circ} 30^{\prime} \mathrm{N}, 99^{\circ} 16^{\prime} \mathrm{E}\right)$.

Fish sampling was collection at each location is carried out once a month, using a stocking net and nets with the help of the fisherman local. The fish samples obtained were put into a plastic bag containing $70 \%$ alcohol and labeled containing information about the data location and sample specifications. Fish-sized big, besides being soaked in alcohol, also injected formalin 4\% (Harahap et al. 2018). Fish specimens before being preserved first photographed and recorded local names, especially for fish species that already have local names.

\section{Observation of fish characteristic}

Length-weight relationship and relative condition factor

Fork length (FL) of all specimens was measured using a digital caliper to the nearest $1 \mathrm{~cm}$ and total weight (TW) of specimens was measured to the nearest $1 \mathrm{~g}$ using a digital balance. The relationship between length and weight was estimated using the equation by Froese et al. (2006): $T W=$ $a F L^{b}$, where $a$ is the constant or linear intercept and $b$ is the coefficient regression or slope when equal to 3 . The $a$ and $b$ parameters were estimated using linear regression on the transformed equation: $\log T W=\log a+b \log F L$ (Silaen and Mulya 2018). The $b$ value may indicate the growth pattern of the fish, which falls into several categories i.e. isometric $(b=3)$ and allometric $(b \neq 3)$, which is further categorized as negative allometric $(b<3)$ and positive allomeric $(b>3)$. Relative condition factor $\left(K_{n}\right)$ was estimated using the equation by Le Cren (1951): $K_{n}=$ $T W_{\text {cal }} T W_{\text {pred }}$, where $T W_{\text {cal }}$ is the bodyweight of fish in $\mathrm{g}$, $T W_{\text {pred }}$ is the predicted body weight generated previously from the length-weight relationship.
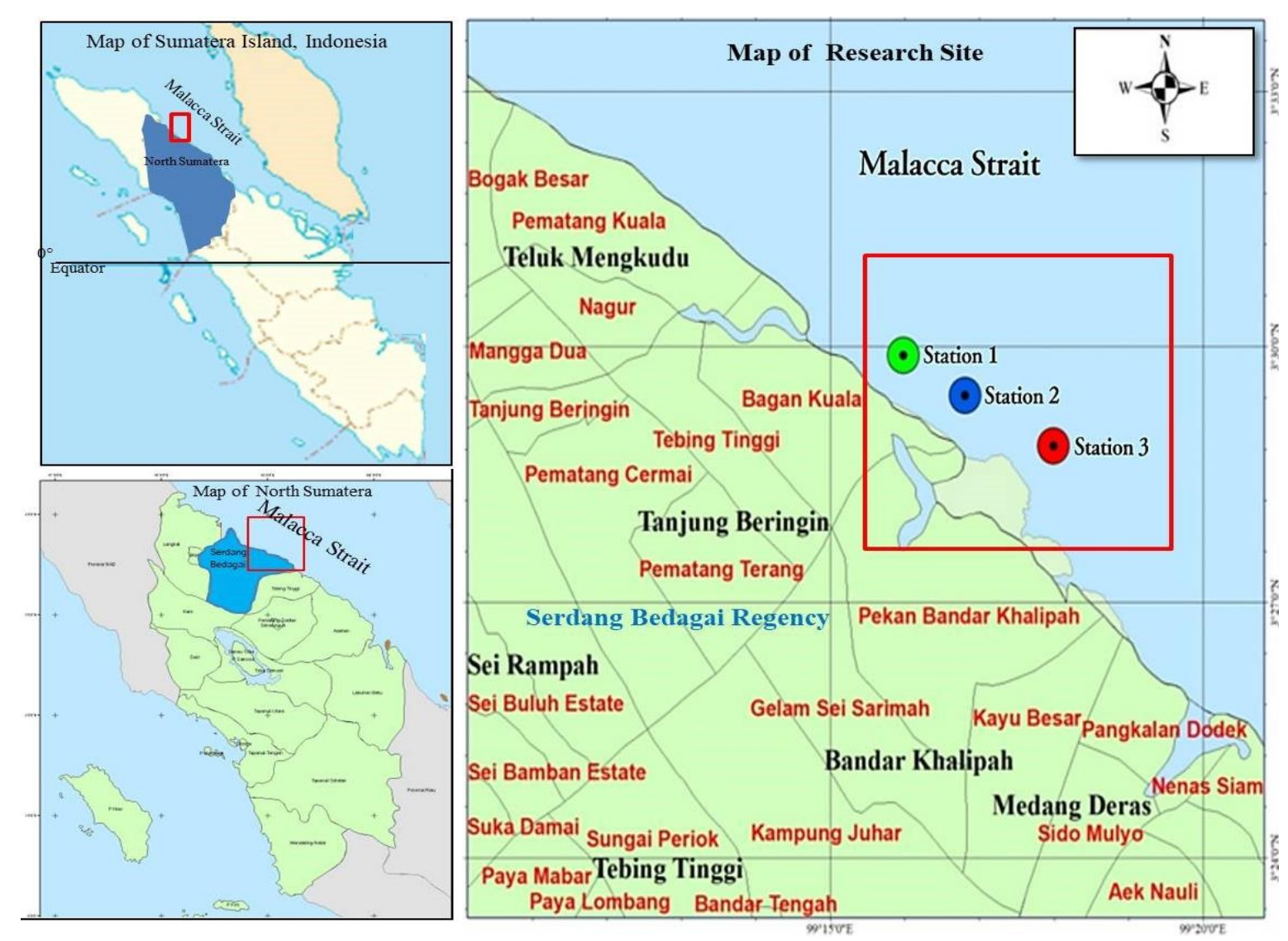

Figure 1. Map of study area showing the sampling sites of Stolephorus waitei in the water region of Malacca Strait, North Sumatra, Indonesia 


\section{Growth parameters}

Fork length (FL) frequency data were used to calculate the von Bertalanffy growth rate $(k)$ using the equation by Sparre and Venema (1998): $L_{t}=L_{\infty}\left(1-e^{-K(t-t)}\right)$, where $L_{t}$ is the length at $t$ age, $L_{\infty}$ is the asymptotic length calculated using the ELEFAN I menu from FiSAT II software (Pauly 1984; Gayanilo et al. 2005), and $t_{0}$ is the anchovy age at zero length. The theoretical age $\left(t_{0}\right)$ was estimated using the equation by Pauly (1983): $\log t_{0}=-0.3922-0.2752 \log L_{\infty}$ $-1.0382 \log k$.

\section{Mortality rate and recruitment pattern}

Natural mortality rate $(M)$ was estimated using an ageindependent method by relating the data of annual water surface temperature $\left(T^{\circ} \mathrm{C}\right)$ with von Bertalanffy growth parameters. The relationship between size (length-weight) and natural mortality was expressed into the equation by Pauly (1980): $\log M=-0.0066-0.279 \log L_{\infty}+0.6543 \log$ $K+0.4634 \log T$. Total instantaneous mortality coefficient ( $Z$ ) was estimated using the catch curves of converted length size featured in the FiSAT II software (Gayanilo et al. 2005) along with the catch mortality $(F)$ and the exploitation rate $(E)$ using the equation by Pauly (1983): $Z$ $=F+M, E=F / Z$. Recruitment pattern of increasing $S$. waitei individuals was analyzed using FiSAT II software (Gayanilo et al. 2005).

\section{RESULTS AND DISCUSSION}

This study investigated the population dynamics of Stolephorus waitei as one of the neglected fish species yet, but widely harvested and trade for commercials originating from the waters of the Strait of Malacca, North Sumatra, Indonesia. Some species of anchovies or whitebaits in the tropical waters between $60^{\circ} \mathrm{N}$ and $50^{\circ} \mathrm{S}$ have been studied (Whitehead et al. 1988). Based on the database of IUCN Red List of Threatened Species, S. waitei is still categorized as data deficient with unknown information of their current population trend, either from its native habitat in Australia or Indonesia and Indo-Pacific: western Indian Ocean (from Cochin and southern tip of India to Myanmar) and western Pacific (Thailand, Java Sea, the Philippines, probably Irian Jaya, if not also Papua New Guinea, south to Queensland; perhaps even more widespread. Based on our study, we obtained 1994 specimens of S. waitei in total during the period of sampling. Fork length (FL) of 1994 specimens was ranged between 4.0 to $6.7 \mathrm{~cm}$ and the total weight (TW) ranged between 0.2 to $2.3 \mathrm{~g}$.

The relationship was formulated as $\log W=0.073+$ $3.0046 \log$ FL or exponentially as $T W=0.073 \mathrm{FL}^{3.0046}$ $\left(R^{2}=0.765\right)$ (Figure 2). Please bring this Figure 2 next to this para. The $b$ value in most of the fish species generally ranged from 2.5 to 4.0 resulting in the dominant isometrical growth (Biswas 1993). The biometrical data simply described the mathematical correlation within two variables to predict the variation from the expected weight for length of the individual fish. In our study, the obtained $b$ value was more than $3(b>3.0)$ which indicated a slight positive allometric or may be close to the isometric growth model for $S$. waitei. Our results also correspond to the previous study on $S$. waitei in Mangalore, India with $b$ value of 3.156 showing the positive allometric growth (Rohit and Gupta 2008). Although the members of Stolephorus are generally small, different growth patterns may exist depending on their habitat conditions. A result was reported by Hazmadi et al. (2011) on $S$. tri in the coastal waters of Terengganu, Malaysia with the obtained $b$ value of 3.038 indicating an isometric growth pattern. Another study by Nair et al. (2015) in Kerala Coast, India obtained the $b$ value of 3.02 for $S$. Commersonii, which was determined as a positive allometric growth pattern by the species. In addition to that, a study of $S$. indicus in Thoothukudi coastal waters of India, revealed a negative allometric growth pattern $(b=2.727)$, which was different from the current findings (Patadiya et al. 2018).

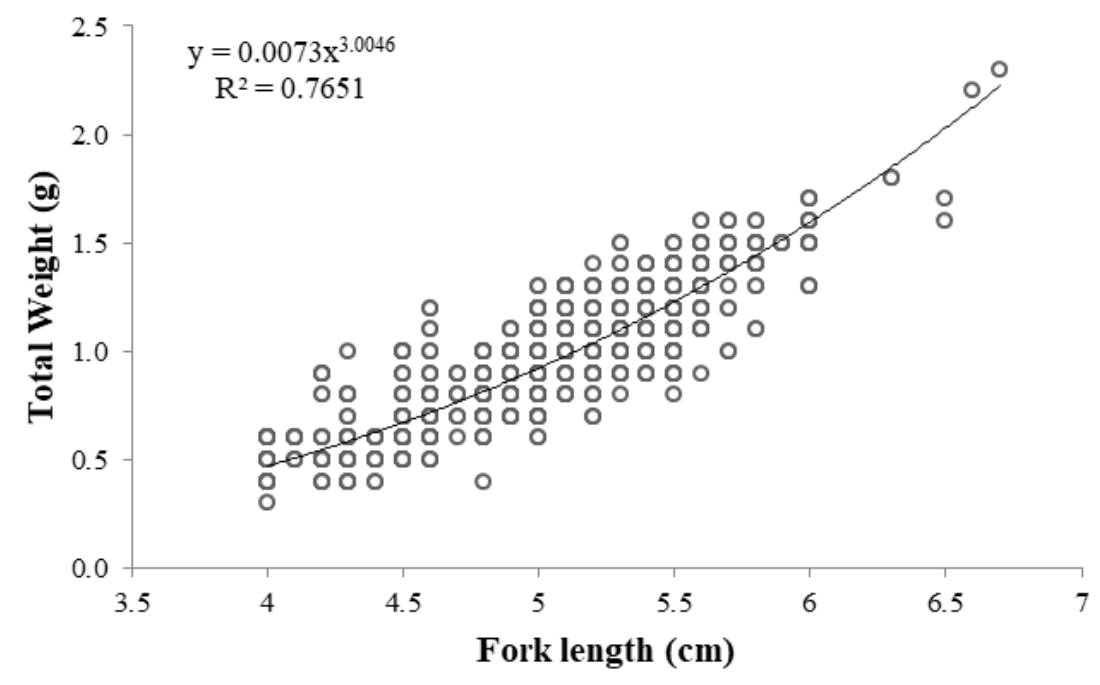

Figure 2. Length-weight relationship of Stolephorus waitei in study area 
The differences of LWRs pattern may due to the seasonal timing of sampling, fish species, maturity state, and co-interaction between biological and abiotic factors (De Giosa et al. 2014; Zaher et al. 2015). Hence, the length-weight relationships (LWRs) analysis is one of the biometrical parameters used widespread to depict the growth of the fish, its general health, and fitness to thrive in its habitat (Froese 2006). The parameter may also show the condition of wellbeing of fish influenced by different biological and environmental factors (Morato et al. 2001). The relative condition factor $\left(K_{n}\right)$ was used to assess the condition of $S$. waitei population in our study. Based on the result, $K_{n}$ was ranged between 1.01 and 1.02 , with the peak in April and June (Figure 3).

In other species, the relative condition factor of Commerson's anchovy (S. commersonnii) in the coastal waters of Kerala, India was reported within 0.78 to 1.95 with the lowest in June $(0.78-0.88)$, which was contradictive and different to present results (Nair et al. 2015). Similar to the current finding, the relative condition factor of $S$. indicus in the coastal waters of India was found within 0.998 in January and 1.008 in June, while being categorized as suitable for the growth of fish population in the region (Patadiya et al. 2018). Condition factor represents the quality of fish individuals based on their physiological conditions as an adaptive result to the interaction between biotic and abiotic factors. In addition, the biometrical data may also represent the well-being status of the fish species. The relative condition factor $\left(K_{n}\right)$ may provide a valuable measure of different life cycle stages of fishes for the implementation of fishery resources management in an ecosystem. The slightly fluctuating result indicated a good and stable growth condition of $S$. waite $i$ in the study area as denoted from $K_{n} \geq 1$ (Le Cren 1951). Many factors are affecting the growth of a fish species including food availability, habitat or environmental conditions, and reproductive cycles (Morato et al. 2001). The estimates of growth parameters of $S$. waitei were $6.56 \mathrm{~cm}\left(L_{\infty}\right)$ with the growth coefficient $(K)$ of $0.34 \mathrm{yr}^{-1}$ and $t_{0}$ of $0 . .651$. The results then showed that $S$. waitei may reach its maximum length of $6.56 \mathrm{~cm}$ at the age of 22 months. The population of S. waitei in the waters of Malacca Strait, consisted of a single age group (cohort), with a shift in the size modus during the month of observation, which shows the monthly growth rate of the population (Figure 4).

Based on Figure 4, it can be seen that the spawning period of $S$. waitei occurs from May to June. Different from our results, a study on $S$. waitei in Belawan Sea, North Sumatra revealed three cohorts that emerged from a certain period in the same habitat (Yuanda et al. 2015). Other studies also reported four to five cohorts of $S$. dubiosus that existed in the Bay Hap and Cua Lon estuaries in Vietnam (Tran et al. 2020). In addition, the von Bertalanffy growth model of $S$. waitei was determined in the formula: $\mathrm{L}_{\mathrm{t}}=$ 6.56(1-e $\left.\mathrm{e}^{0.34(\mathrm{t}+0.06506)}\right)$ (Figure 5).

The annual $K \geq 1.0$ may indicate the fast growth rate of a fish species in a water region. In current study, based on the growth parameters indicated the possible delayed growth of $S$. waitei in the Strait of Malacca, due to the intensive harvesting activity by fishermen. Meanwhile, the growth of $S$. waitei is considered as slow in the Malacca Strait. For comparison, the growth parameters of $S$. waitei in Mangalore were $L_{\infty}=122 \mathrm{~mm}$ and $\mathrm{K}=1.1 \mathrm{yr}^{-1}$, which showed higher results than our study (Rohit and Gupta 2008). The determination of mortality rate was then measured to support our assumption of the growth of $S$. waitei. The total mortality $(Z)$, natural mortality $(F)$, and catch mortality $(M)$ of $S$. waite $i$ were $0.64,1.39$, and 0.75 $\mathrm{yr}^{-1}$ respectively, which is lower than previous study (Luther et al. 1992; Rohit and Gupta 2008). In an ideal exploited stock, catch mortality and natural mortality should be equal to yield an exploitation rate of 0.5 (Gulland 1983).

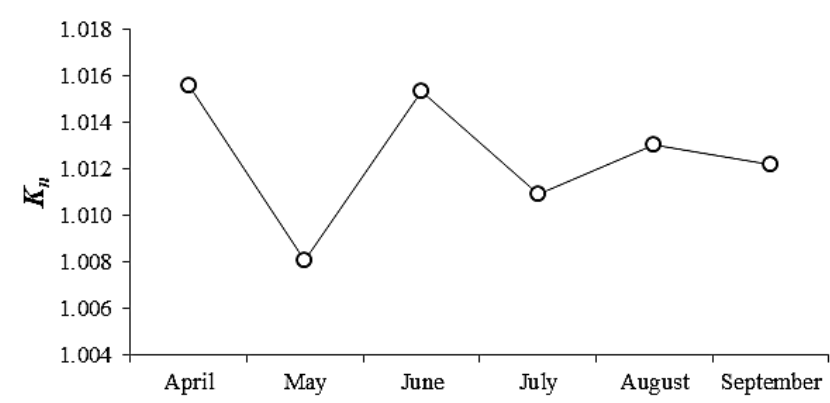

Figure 3. Relative condition factor $\left(K_{n}\right)$ of Stolephorus waitei during the study period

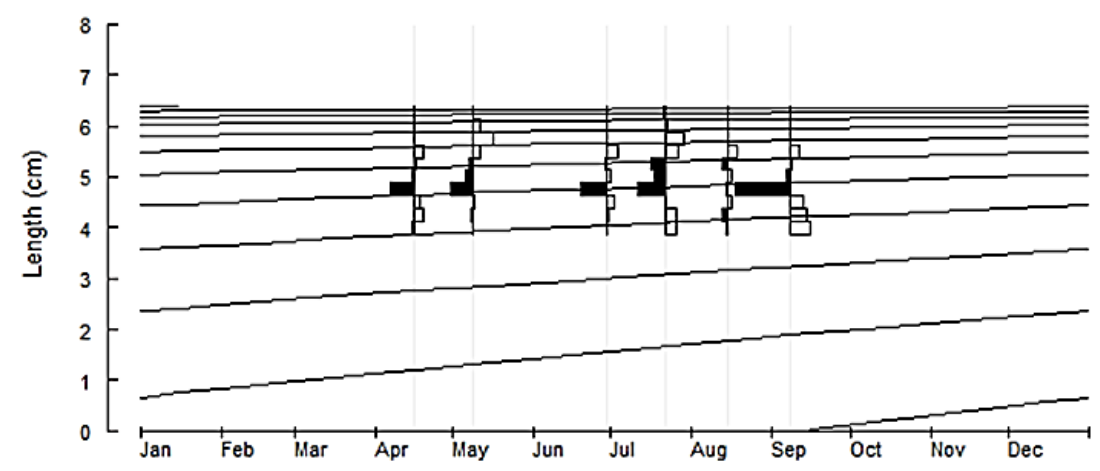

Figure 4. Length frequency distribution of Stolephorus waitei in monthly variation 


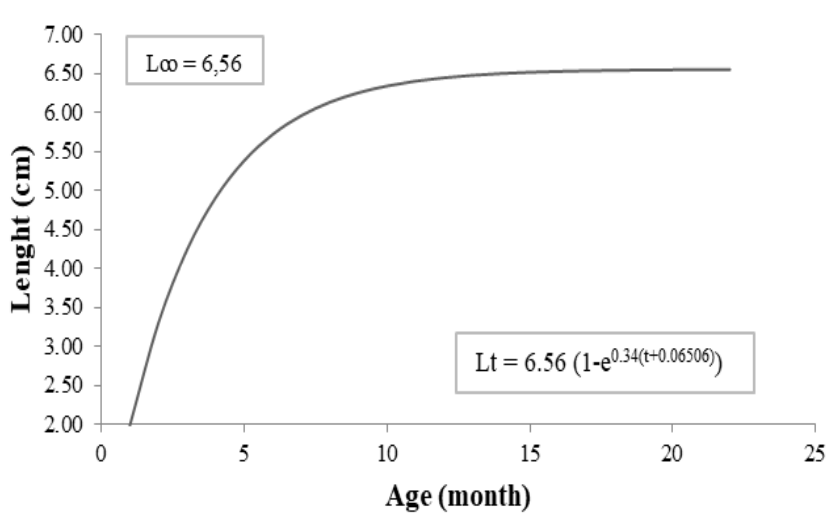

Figure 5. Growth curve of Stolephorus waitei in the study area based on von Bertalanffy model

However, the lower $Z$ than $F$ value indicates that the fishing activities by the fishermen are still considered as normal without any threats to the population decline. Different from our result, the Indian anchovy ( $S$. indicus) in the Inner Ambon Bay experienced massive overfishing and exploitation leading to high mortality (Ongkers 2008). High natural mortality $(F)$ of a fish population in nature may be explained as the constant transfer of mass and energy of a population in an aquatic food web following the ecosystem consequences to prolong the successive future generations (Jorgensen and Holt 2013). The addition of new individuals or recruitment is closely related to population stability and sustainability in nature. The unimodal recruitment and wide distribution pattern for $S$. waite $i$ were observed from its peak in June by $14.21 \%$ with a flat curve from April to August (Figure 6).

Stolephorus waitei population in the waters of the Strait of Malacca, North Sumatra was then categorized in a considerably high $K$ value of population recruitment, showing a good and stable growth condition, and revealing future prospects for aquaculture. Therefore, it is suggested that the fishing activities should be controlled and maintained during the spawning period of $S$. waitei to achieve the sustainability of the population in the future.

\section{ACKNOWLEDGEMENTS}

This research was funded by Ministry of Research Technology and Higher Education, Republic of Indonesia under the scheme of DRPM Research Grant (Contract number 1140A/UN5.1.R/PPM/2018).

\section{REFERENCES}

Biswas SP. 1993. Manual of Methods in Fish Biology. South Asian, New Delhi.

Burbridge PR. 1988. Coastal and marine resource management in the Strait of Malacca. Ambio 17 (3): 170-177.

Cota SEL. 2013. Modeling sardine and anchovy low-frequency variability. Proc Natl Acad Sci USA 110: 13240-13241. DOI: 10.1073/pnas. 1312347110 .

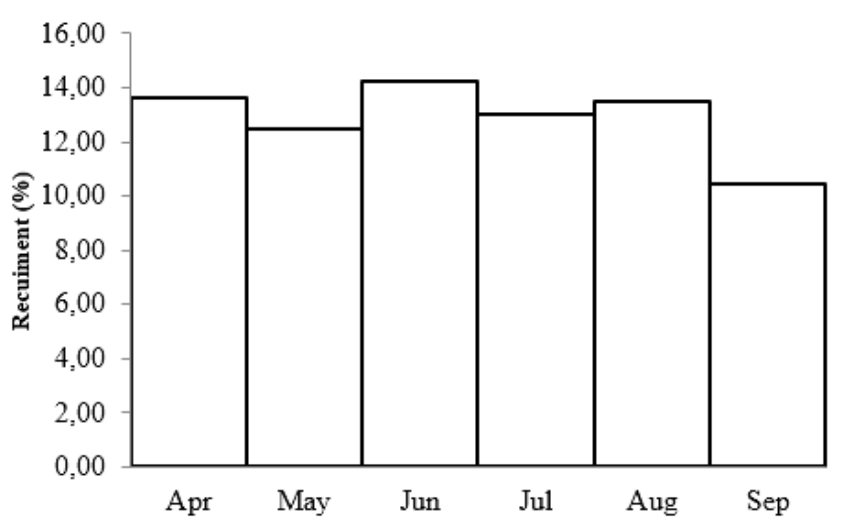

Figure 6. Recruitment pattern of Stolephorus waitei in the waters of Strait of Malacca from January to December 2020

Eschmeyer WN, Fricke R. 2008. Catalog of Fishes. https://research.calacademy.org/ichthyology/catalog/fishcatsearch.html

De Giosa M, Czerniejewski P, Rybczyk A. 2014. Seasonal changes in condition factor and weight-length relationship of invasive Carassius gibelio (Bloch, 1782) from Lesczynskie Lakeland, Poland. Adv Zool 2014: 678763. DOI: 10.1155/2014/678763.

Froese R. 2006. Cube law, condition factor and length-weight relationships: History, meta-analysis and recommendations. J Appl Ichthyol 22: 241-253. DOI: 10.1111/j.1439-0426.2006.00805.x.

Gamawan RP, Suryanti S, Wibawa TA. 2018. Pemetaan wilayah penangkapan ikan teri (Stolephorus sp) berdasarkan data satelit ocean color di perairan Kabupaten Batang. Saintek Perikanan 13: 133-142. DOI: 10.14710/ijfst.13.2.133-142. [Indonesian]

Gayanilo FC, Sparre P, Pauly D. 2005. FAO-ICLARM Stock Assessment Tools II: FiSAT II: User's Guide. WorldFish Center, Rome.

Gulland JA. 1985. Fish Stock Assessment: A Manual of Basic Methods. Wiley and Sons, New York.

Harahap A, Barus TA, Ilyas S, Mulya MB. 2018. Macrozoobenthos diversity as bioindicator of water quality in the Bilah river, Rantauprapat. J Phys Conf Ser 1116: 052026. DOI: 10.1088/17426596/1116/5/052026.

Hata H. 2020. Stolephorus waitei. The IUCN Red List of Threatened Species 2020: e.T170766737A170767007.

Hata H, Lavoue S, Motomura H. 2019. Taxonomic status of seven nominal species of the anchovy genus Stolephorus described by Deslman (1931), Hardenberg (1933), and Dutt and Babu Rao (1959), with redescriptions of Stolephorus tri (Bleeker 1852) and Stolephorus waitei Jordan and Seale 1926 (Clupeiformes: Engraulidae). Ichthyol Res 67: 7-38. DOI: 10.1007/s10228-019-00697-7.

Hazmadi MZ, Amin SMN, Arshad A, Rahman A, Al-Barwani SM. 2011. Size frequency and length-weight relationships of spined anchovy, Stolephorus tri from the coastal waters of Besut, Terengganu, Malaysia. J Fish Aquat Sci 6: 857-861. DOI: 10.3923/jfas.2011.857.861.

Innawati R, Surilayani D, Susanto A, Munandar A, Rahmawati A. 2018. Potential yield and fishing season of anchovy (Stolephorus sp.) in Banten, Indonesia. AACL Bioflux 11 (3): 804-809.

Jordan DS, Seale A. 1926, Review of the Engraulidae, with descriptions of new and rare species. Bull Mus Comp Zool Harvard 67: 355-418.

Jorgensen C, Holt RE. 2013. Natural mortality: Its ecology, how it shapes fish life histories, and why it may be increased by fishing. J Sea Res 75: 8-18. DOI: 10.1016/j.seares.2012.04.003

Le Cren CD. 1951. The length-weight relationship and seasonal cycle in gonad weight and condition in perch, Perca fluviatilis. J Anim Ecol 20: 201-219. DOI: 10.2307/1540.

Luther G, Rao KVN, Gopakumar G, Muthiah C, Pillai NG, Rohit P, Kurup KN, Reuben S, Devadoss P, Rao GS, Bennet PS, Radhakrishnan NS. 1992. Resource characteristics and stock assessment of whitebaits. Indian J Fish 39 (3\&4): 152-168.

Masse J, Sanchez F, Delaunay D, Robert JM, Petitgas P. 2016. A partnership between science and industry for a monitoring of anchovy $\&$ sardine in the Bay of Biscay: When fishermen are actors of science. Fish Res 178: 26-38. DOI: 10.1016/j.fishres.2015.11.018. 
Milton DA, Andamari R, Rawlinson NJF. 1998. The biomass of tropical anchovies (Encrasicholina species) at Bacan, Eastern Indonesia estimated by the daily egg production method. Indon Fish Res J 4: 58 65. DOI: 10.15578/ifrj.4.2.1998.58-65.

Morato T, Afonso P, Lorinho P, Barreiros JP, Sanstos RS, Nash RDM. 2001. Length-weight relationships for 21 coastal fish species of the Azores, North-eastern Atlantic. Fish Res 50: 297-302. DOI: 10.1016/s0165-7836(00)00215-0.

Nair PG, Joseph S, Pillai VN. 2015. Length-weight relationship and relative condition factor of Stolephorus commersonii (Lacepede, 1803) exploited along Kerala Coast. J Mar Biol Ass India 57: 27-31. DOI:10.6024/jmbai.2015.57.2.01856-04.

Ongkers O. 2008. Parameter populasi ikan teri putih (Stolephorus indicus) di Teluk Ambon bagian dalam. Jurnal Iktiologi Indonesia 8 (2): 85 92. [Indonesian]

Patadiya DS, Jawahar P, Jayakumar N, Pereira JJ. 2018. Length-weight relationship and relative condition factor of Indian anchovy Stolephorus indicus (van Hasselt, 1823) from Thoothukudi coastal waters. J Entomol Zool Stud 6 (2): 279-282.

Pauly D. 1980. On the interrelationships between natural mortality, growth parameters, and mean environmental temperature in 175 fish stocks. ICES J Mar Sci 39: 175-192. DOI: 10.1093/icesjms/39.2.175.

Pauly D. 1983. Some Simple Methods for The Assessment of Tropical Fish Stocks. FAO Fisheries Technical Paper, Rome, Italy.

Pauly D. 1984. Fish Population Dynamics in Tropical Waters: A Manual for Use with Programmable Calculators, ICLARM. FAO Fisheries Technical Paper, Rome, Italy.

Rohit P, Gupta AC. 2008. Whitebait fishery of Mangalore - Malpe, Karnataka during 1997-2002. Indian J Fish 55 (3): 211-214.

Safruddin, Hidayat R, Zainuddin M. 2018. Effects of environmental factors on anchovies Stolephorus sp. distribution in Bone Gulf, Indonesia. AACL Bioflux 11 (2): 387-393.
Silaen SN, Mulya MB. 2018. Density and white shrimp growth pattern (Penaeus merguiensis) in Kampung Nipah waters of Perbaungan, North Sumatra. IOP Conf Ser Earth Environ Sci 130 (1): 012044. DOI: $10.1088 / 1755-1315 / 130 / 1 / 012044$

Siriskar DA, Khedkar GD, Lior D. 2013. Production of salted and pressed anchovies (Stolephorus sp.) and its quality evaluation during storage. J Food Sci Technol. 50: 1172-1178. DOI: 10.1007/s13197-011-04509.

Sparre P, Venema SC. 1998. Introduction to Tropical Fish Stock Assessment. FAO Fisheries Technical Paper, Rome, Italy.

Tran DD, Nguyen VT, Dinh QM. 2020. Population dynamics of Stolephorus dubiosus in Bay Hap and Cua Lon estuaries, Mekong Delta, Vietnam. AACL Bioflux 13 (4): 2250-2264.

Whitehead PJP, Nelson GJ, Wongratana T. 1988. FAO Species Catalogue, vol 7: Clupeoid Fishes of The World (Suborder Clupeoidei). An Annotated and Illustrated Catalogue of The Herrings, Sardines, Pilchards, Sprats, Shads, Anchovies and Wolf-herrings. Part 2: Engraulidae. FAO, Rome.

Wongratana T, Munroe TA, Nizinski MS. 1999. Engrulidae. In: Carpenter KE, Niem VH (eds). FAO Species Identification Guide for Fishery Purpose, The Living Marine Resources of The Western Central Pacific. FAO, Rome.

Yuanda D, Mulya MB, Muhtadi A. 2015. Pertumbuhan dan laju eksploitasi ikan teri pekto (Stolephorus waitei) di Perairan Belawan Kota Medan Sumatera Utara. Aquacoastmarine 15 (1): 120-130. [Indonesian]

Zaher FM, Rahman BMS, Rahman A, Alam MA, Pramanik MH. 2015. Length-weight relationship and GSI of hilsa, Tenualosa ilisha (Hamilton, 1822) fishes in Meghna river, Bangladesh. Intl J Nat Soc Sci 2 (3): 82-88. 